\title{
Befogadott egy cigány falu - nagy élmény! Interjú Kereszty Zsuzsával
}

\section{Kolosai Nedda}

az Eötvös Loránd Tudományegyetem Tanító- és Óvóképző Karának egyetemi docense kolosai.nedda@tok.elte.hu

DOI: 10.37205/TEL-hun.2019.1-2.07

Kereszty Zsuzsával 2017 májusában egy napfényes napon, reggeltől beszélgettünk. Határozottan, őszinte kedvességgel mondta meg, meddig ér rá. Életútinterjút készítettünk, időre. És minden, ami a kérdezőnek fontos volt, belefért. Mesélt az iskoláskorában megfigyelt jegenyefáról, gimnazistakori teázásáról Szabó Lőrinccel és Juhász Ferenccel. Arról gondolkodott, az iskola, a tanárai, saját tapasztalatai milyen módokon alakították életszemléletét és pedagógiáról való gondolkodását.

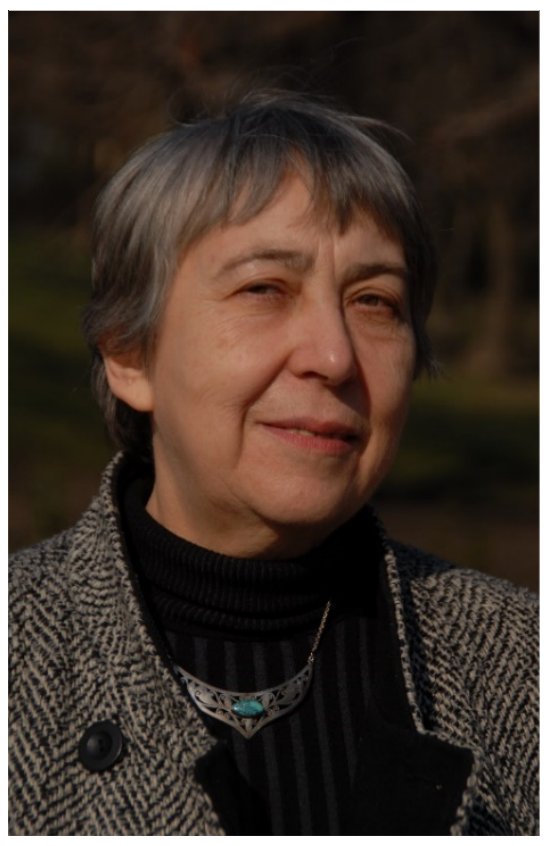

Köszönöm szépen, hogy elfogadtad ezt az interjút! Azt szeretném kérni tőled, képzeld el az életedet, mint egy utat, amely a jövóben folytatódik, a múltban elkezdödött. Most sétálj vissza ezen az úton, egészen addig, amíg óvodás és iskolás voltál! Hogyan emlékszel az óvodádra, az iskolád első éveire?

A Sas-hegyen laktunk, közel a Tanítóképzőhöz. Egy magánóvodába íratott anyám, ahová nem szerettem járni. Előttem van egy kép: megyek haza az óvodából, és azon gondolkodom, mit kellene anyámnak mondanom, hogy ide soha többet ne küldjenek. Azt kell mondanom, jöttem rá, hogy minket ott nem visznek levegőre. Anyám valamiért ezt elhitte, vagy csak megértette, hogy nem szívesen megyek, és nem kellett óvodába járnom. Otthon akartam maradni.

Első osztályba két hónapig jártam, akkor folyt Budapest ostroma. Írni-olvasni a Dayka Gábor utcai óvóhely egyik sarkában a bátyámtól és Móra Ferenc Arany 
Zengő $A B C$-jéből tanultam. Mikor konszolidálódott a helyzet, anyám oda íratott engem is, ahová a bátyám már három éve járt, a Domokosné Löllbach Emma által alapított Új Iskolába. Régóta tudom, hogy egész pályám szempontjából meghatározó az, ami ott velünk történt. Annak ellenére, hogy az iskolák államosításáig ez mindössze három és fél Új Iskolában töltött év volt.

\section{Egyszerűen csak együtt éltünk a tanítókkal az Új Iskolában}

Volt egy számtanfüzetünk és egy naplónk, semmi más. A naplóba leírtuk, lerajzoltuk, ami éppen történt az osztállyal. Élt egy cinke a teraszon, őt figyeltük, abban az időben épült a Sió-csatorna, kimentünk az iskolaudvarra, és agyagból, homokból megépítettük a csatorna medrét. Ki kellett választanunk egy lakásunkhoz közeli fát. Jegenye volt a kertünkben, azt kellett ősszel, télen, tavasszal lerajzolni, írni róla. Ma is más közöm van a jegenyéhez, mint a többi fához.

Az Ujj Iskola számomra meghatározó élmény volt. Hosszú ideig azt hittem, ezt eltúlzom. De a Domokosné születésének 100. évfordulójára rendezett konferencián beszédet mondott Göncz Ârpád, aki az első négy elemit szintén ott végezte, és arról beszélt, hogy ez a négy év meghatározó volt a számára. Kiderült, ezzel az élménnyel nem vagyok egyedül.

Az iskolák államosítása után a Németvölgyi Úti Általános Iskolába jártam, hatodiktól nyolcadikig. A kontraszt elképesztően erős volt! Utólag visszagondolva, csak egy átlagos állami iskola volt. Jó volt a magyartanárnőnk, ez a tárgy fontos volt nekem, de ammóniaszagú volt a folyosó, valamint az osztálytársak, a tanárok és a gyerekek közti kapcsolatot tekintve a két iskola légkörében óriási volt a különbség. Megint kitaláltam valamit, most se volt igaz, azt meséltem az ismerősöknek, amire vágytam, hogy összebeszéltünk az osztálytársaimmal, és egy napra az egész osztály megszökött az iskolából. A Németvölgyi után újra nagyon jó időszak következett, a Szilágyi Gimnáziumba kerültem.

Meghatározó tanitó, pedagógus személyiségre emlékszel ebből az iskolai időszakodból?

Az Új Iskolában volt egy fantasztikus alsós tanítónő, Kápolnási Hermin, aki még kilencven évesen is utazgatott a nagyvilágban, akár repülőn is. Melegszívű, okos ember volt. De mégsem rá emlékszem úgy, mint erős hatású személyiségre, hanem az angol tanárnőre, Oli nénire, Orfanidesz Olimpiára. Vékony, könnyed járású, szinte légies, sugárzó nő volt. Nagyon kevés óránk volt vele hetente, és még- 
is... Egyszer, évtizedekkel később, egy nehéz élethelyzetben elgondolkoztam, milyen is szeretnék lenni tulajdonképpen, és Oli néni jutott eszembe. Sose leszek olyan, se alkatilag, se a stílust tekintve, de ő mint ideál megmaradt. (Zárójelben jegyzem meg, hogy amikor rá visszaemlékeztem, már itt laktunk a Logodi utcában, s ahogy eszembe jutott, úgy jelent meg előttem, mintha itt jönne fel a lépcsőn a Mikó utca felőli oldalon. Később, az Új Iskola egyik évkönyvéből tudtam meg, hogy Oli néni is a Logodi utcában lakott, akkori lakását csak néhány ház választja el a házunktól. Sokszor jöhetett fel a Mikó utcai lépcsőn, de erről tapasztalatból nem tudhattam. Ez lehet véletlen egybeesés is, én többet láttam benne.) Meghatározó tanár-élményem már csak a gimnáziumból van.

Konkrét pozitív iskolai élményre emlékszel ebből az iskolai időszakodból? Megpróbálnál felidézni egy konkrét pozitív élményt az elsô évekből?

Volt egy nagyon jó barátnőm, aki kiskamasz korában meghalt rákban, vele sokat sétáltunk az iskolaudvaron. Ez nem iskolai élmény igazán, de nekem az iskolához, mint helyszínhez kötődik. Ott vitatkoztunk nyolcévesen az udvaron újra és újra érvelve Isten létéről vagy nem létéről.

Az Új iskola mellett Neveléslélektani Kutatócsoport müködött. Megalapítója, vezetője, a gondolkodás-lélektannal foglalkozó Baranyai Erzsébet volt. Minden évben készítettek velünk egyénként, nyelvi fejlettséget vizsgáló tesztet. Szavak jelentését kellett értelmezni. Emlékszem, egyszer nem tudtam, mit jelent, hogy „válogatják a legények elejét”. Erős élményem, ahogy lekvárt főztünk, a kezem „emlékszik” az agyagra, amelyből a Sió-csatorna oldalfalait építettük, emlékszem, ahogy álltam és figyeltem választott fámat, a jegenyét.

Ahogy visszatekintesz, most már ezekkel a tapasztalatokkal, gondolatokkal, mi volt a különbség a két iskola között a Németvölgyi Általános Iskola, meg az Új Iskola között számodra?

Az Új Iskolában együtt éltek velünk a tanítók, együtt próbáltuk felfedezni, ami körülöttünk történt. Cselekedetünk és egyéni naplóban jegyeztük a tapasztalatainkat. Gyüjtöttünk a szegényeknek, felírtuk, hány kiló liszt, krumpli, cukor gyült össze, mindezt hova vittük, kinek adtuk át. Karácsony előtt együtt választottuk ki, melyik régi zsoltárt fogjuk megtanulni. A másodikban kiválasztottat most is tudom. Kiválasztottuk, beírtuk a naplóba, megtanultuk. Együtt éltünk. Ahogy egy családban arra figyelnek, hogy a gyerek töltekezzen is, miközben jelen van és 
részt vesz a felnőttek tevékenységében. A Németvölgyiben meg becsöngettek, beültünk a padba, jött a tanár, felelni kellett. Szóval az Új Iskolában átélni, lejegyezni, lerajzolni kellett, a Németvölgyiben megtanulni, azután felelni belőle. Számomra az iskolaélmény: az Uj Iskola-beli közös tapasztalás. Azt, hogy egy tanár által „leadott, elmondott anyagból” felelni kell, hatodikban tapasztaltam először. Jöhet a gimnázium?

Igen, kérlek szépen!

1956-ban érettségiztem, '52 és '56 között jártam a Szilágyiba, ${ }^{1}$ ahol akkor egyetemi katedrájuktól megfosztott tanárok is tanítottak. Kimagasló intellektussal, tudással jöttek a felsőoktatásból. Magyartanárom, aki számomra meghatározó személyiség, Baránszky fób László Kolozsváron volt az Irodalomtudományi Tanszék vezetője, esztétika professzor. Ő tanította a magyart, és ő volt a helyettes osztályfőnökünk. Kratofil Dezső, a szegedi Cselekvés Iskola egyik alapítója volt a matematika tanárunk, Fraknói Tibor tanította a kémiát. Kimagasló egyéniségek voltak, akik középiskolába kerülve nem érezték magukat valamitől megfosztottnak. Egyszerủen élvezték az új helyzetet, legalábbis akkor mi így láttuk. Baránszky minden egyes órára a hóna alatt könyvek sokaságát hozta. Előfordult, hogy az egyik cipője szürke, a másik fekete volt, mégsem nevettük ki. Felolvasott, beszélt, és mintha magával egyenrangúnak tekintett volna minket. Közben finom, közvetett módon úgy nevelt, hogy ezt utólag csak csodálni tudom! Édesanyám tanár volt. Néhányunkon kívül, ez az osztály budai úrilányok gyülekezete volt, kivéve egy „házmesterlányt” is, akit az úrilányok - ezt lehetett érezni a levegőben - lenéztek. $B a-$ ránszky tanár úr egyszer csak így szólt hozzá: „Kedves Ági! Erről mi a véleménye?” A tárgy, amelyről Baránszky véleményt kért, utólag közömbös. Ettől a kérdéstől kezdve Ági véleménye érdekelte az osztályt is.

Egy ideig egy szép, piperkőc, elsősorban külsőségekre figyelő lány véleménye befolyásolta az osztályt. Rákospalotai, szegényebb fiúkból álló osztállyal jártunk együtt tánciskolába. Ez a lány lenézte a rákospalotai fiúkat, azt hangoztatta, előkelőbb fiúkkal kellene táncolnunk. Egyik órán Baránszky tanár úr Baudelaire-t idézett. Az idézett sorokra ma is a fülemben vannak:

„...van szépség, melyet méltó, hogy megcsodáljon

a méla vágy, pedig mélyén titok nem ég,

ékszertelen tok és emléktelen medáljon,

${ }^{1}$ Szilágyi Erzsébet Gimnázium, Budapest I. kerület. 
mélyebb és üresebb nálad is üres ég."

Emlékszem a vers utáni csendre. Megértettük, miért idézte ezt a tanár úr. Dalma tekintélyének vége volt. Az osztály értékrendjében a megfelelő helyre került.

\section{Teázás Szabó Lőrinccel és Juhász Ferenccel}

A magyar dolgozatra lehetett ötös, jeles és kitűnő osztályzatot kapni a gimnáziumban. Aki kitűnőt kapott, az abban a hónapban együtt teázhatott egy íróval. Szabó Lőrinccel, Juhász Ferenccel közös teázásra emlékszem. Új verseikből olvastak fel, a tanár úr pedig olyan kérdéseket tett fel nekik, hogy válaszaik nekünk is fontosak lehessenek. A Huszonhatodik évet (Szabó Lőrinc) és Juhász Ferenc Virágok hatalmát ma is másképp olvasom. Létrejött, nyilván a kamaszkor lelkesedésébe ágyazva egy személyes kapcsolat jelentős költők műveivel. Ezek a teázások fontos események voltak a gimnázium életében. A Szilágyi ebben az időben remek hely volt!

Személyes köszönni valóm is van a Szilágyinak. Korán önállósodtam. Otthoni vallásos nevelés és a család tudta nélkül, befogadó közösséget keresve, tagja lettem a Barlay Szabolcs ciszter szerzetes által vezetett illegális hittancsoport-hálózatnak. Először tanultam, aztán nálam egy-két évvel fiatalabbaknak tanítottam is hittant. Ebből az Államvédelmi Hatóság államellenes összeesküvést kreált. Negyedikes koromban egy napon kihallgatásra idéztek a Gyorskocsi utcába. Otthon nem mertem szólni az idézésről, iskolai hiányzásomat nem tudtam igazolni. Meglepetésemre a gimnáziumban arról a napról senki sem kért tőlem igazolást, az osztályfőnököm úgy tett, mintha nem is tudná, hogy aznap nem voltam ott. Évtizedekkel később mondta el Bálint Béla igazgató úr egy osztálytalálkozón, hogy őt az ÁVH értesítette az „államellenes cselekményben” való részvételemről. Bálint Béla ennek ellenére - '56 tavaszát írtuk ekkor -, egyetemre javasolt. A Szilágyi Erzsébet Gimnázium sziget volt, számomra legalábbis.

Elgondolkodtató, rendkívüli történetek. Részben utaltál a családodra. Megtennéd, hogy kicsit mesélsz a családodról?

Az apám családja német gyökerü, egyik ágon német zsidó, a Kereszty a Kerst név magyarosított változata. (Sok évvel később heidelbergi telefonkönyvben kerestem és tucatszámra találtam Kerst vezetéknevet.) Dédapám katonaorvos volt, a szabadságharc egyik csatája után, a sebesült Görgeyt is kezelte. Ő hol Kerst, hol 
Kereszty Bélaként szerepel a hadtörténeti levéltár orvoslistáin, valószínűleg ő magyarosította a nevünket Kerstről Keresztyre.

Anyám felmenői, addig, amíg a családi emlékezet egyáltalán tart, erdélyi református papok vagy tanítók. Szüleim későn házasodtak össze, nem tudtak összecsiszolódni. Az otthoni légkörre erős feszültség volt jellemző, így nagyon korán elkezdtem kifelé élni. Nagyon pozitív viszont, hogy anyám, aki biológia és testnevelés szakos tanár volt, pontosan tudta, milyen a jó iskola, ezért íratott minket a bátyámmal az Új Iskolába. A gimnáziumot már én választottam, de az Ujj Iskolát anyámtól kaptam, s ahogy említettem, ez életre szóló hatás, nagy érték. Anyám a gyerekkorát Erdélyben, természet közelben töltötte, családja Trianon után települt Magyarországra. Fontos volt számára, hogy legalább a nyarakat ne városban töltsük. Amikor erre nem volt pénz, akkor gyerekeket nyaraltatva nyaraltunk mi is. A bátyámmal nagyon jóban voltunk, vagyunk ma is. Ő 1956-ban disszidált, ciszter szerzetes lett, egy magyar alapítású texasi monostorban él, a monostor gimnáziumában, és a texasi egyetemen tanít.

Azt mondtad: úrilányok...

Utólag tudtam meg, hogy az ő csoportjukból ki voltam közösítve.

Te magad hogyan találtad meg a helyed az osztályodban?

Negyvenketten voltunk az osztályban. Ott volt Éva, akiről tudtuk, hogy egy ávós tisztnek a lánya, Ági, aki házmesterlány volt, és a többiek, a „budai úrilányok”. Jó barátaim voltak az osztályban, olyanok, akiken ez az úrilányság számomra akkor nem látszott! A gimnáziumi éveim alatt mi szegények voltunk, nekem például négy évig nem volt tornacipőm, nem volt rá pénz, míg Rusznyákéknál mindig tejszínhabos kakaóval kínáltak. Szüleim nyugdíjasok voltak, anyám később visszament tanítani a Márvány utcai Általános Iskolába, az apámnak volt valami minimális nyugdíja. Barátként ott voltak az osztályban a szegényebb, értelmes lányok. A jómódúak közül Marek Vera, és az akkor számomra különös, nálunk sokkal érettebb Rusznyák Márta - Márta édesapja volt az MTA elnöke -, mindkettőjükkel a mai napig jóban vagyunk. Aztán ott voltak a „katonatiszti különítmény” lányai. Negyven évvel később (!) 2000-ben, egy osztálytalálkozón, egyikük megkérdezte „Miért nem mondtad, hogy neked is katonatiszt az apád? Bevettünk volna!”. Annak idején az ÁVH-s tiszt lányát akartam éppen megtéríte- 
ni, együtt jártunk haza, jókat beszélgettünk, szóval észre sem vettem, hogy valahonnan ki vagyok rekesztve...

Jól éreztem magam a gimnáziumban, jó tanuló voltam, ott voltak kiváló tanáraink, Molière-darabot adtunk elő, abban nőként még nem azonosítva magam férfiszerepet játszottam. Tiszta lányosztály volt, többen játszottunk férfiszerepet. Jó légköre volt a gimnáziumi évek szinte minden napjának. Utólag, az osztálytalálkozókon láttam, hogy a társaság egy részének a szemében mennyire a peremen voltam. Elfogadtak mint értelmes, vallásos lányt - akkor az voltam -, de nem érezték úgy, hogy az osztály magjához tartozom.

Árnyalja a képet, hogy a '90-es években az egyik osztálytársammal, akivel nem voltunk barátok, de gimnazistákként jókat beszélgettünk, amikor összetalálkoztunk, kiderült, melyik pártra szavaztam. Ettől kezdve szilágyis osztálytalálkozókra nem hívtak. Ez úgy meglepett, hogy mintegy tíz évvel később, mikor újra hívtak, nekem nem volt kedvem elmenni. Azután szóltak, felejtsük el, jöjjek újra. Időnként elmegyek, de a távolságtartás megmaradt.

Utólag persze sok minden átszíneződik, utólag a „tiszti különítmény” lányai között is láttam egy kiválót, aki közben nagyon szép egyéniséget bontott ki magából. Most nyolcvanasokként találkozgatunk, beszélgetünk a gimnáziumi évekről. A gimnáziumi élmények közösek, de számomra most is idegen, ahogyan ők a világról gondolkoznak.

Azt mondtad, a családod nem volt vallásos, te mégis valahogy kialakitottad ezt magadban. Most pedig azt mondtad, hogy „akkor még”.

Egy impulzív kamasz, akinek nincs otthon érzelmi fogódzója, biztonságot keres. Volt egy osztálytársam, aki benne volt egy hittancsoportban, és egyszer elhívott. Elmentem, megkedveltek. A csoportot egy könnyed, derűs, életigenlő, gyönyörűen hegedülő apáca vezette, a közvetítésével ismertem meg azt a fajta kereszténységet, amely tényleg a szeretetre, az egyenlőségalapú gondolkodásra épül. 14 évesen, a szüleim tudta nélkül katolizáltam, aztán természetes lett, hogy én is csoportot vezetek, rám bíznak gyerekeket, tanítom őket arra, amit átéltem... Később rájöttem, hogy ez nem vallásosság. Bizonyosságot kerestem, köszönöm, az megvan. Később már nem volt csoportom, már nem vállaltam, de ekkor lett a dologból a bírósági ügy, az a bizonyos tanúkihallgatás! A transzcendenshez azonban most is van közöm.

Hogyan választottál egyetemet? 
Nem egyetemet, szakot választottam. Természetes volt a magyarszak, hiszen versek, egyáltalán olvasás nélkül nem tudtam létezni. A szomszéd házban volt egy barátnőm, a kertjükben egy nagy gesztenyefa. Ha nagyon untam a családomat, átmentem, felmásztunk a gesztenyefára, és olvastunk. Aztán ott volt Baránszky tanár úr, mint követhetetlen, de mégis minta. A magyarszak tehát nem volt kérdés. Kellett hozzá egy másik szakot is választani. Nincs jó nyelvérzékem, így nem idegen nyelvet, hanem a történelmet választottam. Elöző évben dolgozatom díjat nyert történelemből a Rákosi Mátyás tanulmányi versenyen, ez előnyt jelentett a felvételnél. A forradalmakról szóló dolgozat jeligéje fózsef Attila Hazám című versének ez a sora volt: Föl kéne szabadulni már! 1955-ben vagyunk, és április negyedikén volt az eredményhirdetés. Jellemző a politikai légkörre, hogy szegény történelem tanárnőm nagy zavarban volt, vajon fel lehet-e olvasni ezt a négy szót a felszabadulás ünnepén. Végül az eredményhirdetésnél nem jelige, hanem név szerint szólított fel.

A Szilágyi igazgatójának későbbi közlése szerint, „a katonatiszt édesapját úgy eltűntettük az életrajzából, mintha nem is lett volna”. Így fölvettek. Az „egyéb származású” helyett tanár anyám révén már „értelmiségi származásúként” tartottak nyilván. De ekkor már '56 volt! 1956 tavaszán volt a felvételi...'56 előszele már jelen volt, már működött a Petőfi-kör. Szóval nem egyetemet választottam, hanem a magyar-történelem szakot.

\section{Értem... Milyen meghatározó egyetemi élményedre emlékszel?}

1956 életem legnagyobb élményei közé tartozik. Azt átélni, hogy egy társadalomnak lehet kegyelmi állapota, meghatározó élmény, ez a jelző pontosan illik erre a néhány napra. Két mozzanatot mesélek el.

Október 6-án temették újra Rajk Lászlót. Bementünk reggel az egyetemre, a felsőbb évesek közölték, hogy ma nincs tanítás, megyünk a Rajk-temetésre. Úgy állították össze a sorokat, hogy egy sor felsőévest egy sor gólya kövessen. A Blaha Lujza téren, az egykori Nemzeti Színház előtt megállt a menet, ketten a vállukra kaptak egy másodéves fiút, Kelemen Elemért, aki később fóigazgatója is volt a Tanítóképző Főiskolának. Elemér elszavalta az Új tavaszi seregszemlét. Mentünk a Kerepesi úti temető felé, a Keletinél újra megálltunk, és egy másik fiú elszavalta Ady Endre Rohanunk a forradalomba című (!) versét. Kiértünk a temetőbe, az első sorokban vitték az ELTE koszorúját. Rajk László koporsója előtt nem állt meg a menet, szájról szájra terjedt: „a koszorút nem ide hoztuk.” Tüntetőleg továbbvo- 
nultunk, a Hősök terén álltunk meg, a koszorút az Ismeretlen hősök sírjára tették a felsőéves szervezők, majd elindultunk az Andrássy úton. Megálltunk az Andrássy út 60 előtt. Ott valaki elszavalta fózsef Attila Levegőt című versét. „Én nem ilyennek képzeltem el a rendet" mondtuk már kórusban együtt. Innen vissza az egyetemhez, ott skandáltuk, hogy „Éljenek a bátor magyar írók!”, „Fakultatív oktatást!”, „Tanítsatok igazat”. Történelem szakosként ugyanis heti hat órában a Szovjetunió történelmét tanultuk, egyetemes történelmet pedig összesen heti kettőben. Mindent a felsőévesek készítettek elő, mi gólyák, néhány hete egyetemisták, boldogan vonultunk, skandáltuk a jelszavakat velük. Ez volt az első egyetemi élményem.

Utána elkezdődött a tanítás... abból a vulgár marxizmusból, amelyet történelem címén tanítottak, egy félév alatt elegem lett. Ezt fogom majd tanítani? - kérdeztem magamtól.

Szerencsére Radnai Béla személyében volt egy zseniális pszichológia tanárunk, aki nekünk, tanár szakosoknak általános pszichológiát adott elő úgy, hogy elképedtünk attól, így is lehet nézni a világot.

\section{6 őszén ez megtörténhetett: hatunknak új szakot indítottak}

Az első félév végén felmentünk hatan az ELTE Lélektan Tanszékére, és elmondtuk, hogy szeretnénk pszichológia szakosok lenni. Kardos Lajos volt a tanszékvezető, aki kérésünknek nagyon megörült, hiszen az '50-es években nem volt pszichológia szak, így a szak velünk indulhatott újra.

Leadtuk a történelem szakot mind a hatan, és felvettük a pszichológiát. Szépséges négy évünk kezdődött, hiszen az új szak szerkezete, tanterve velünk született. Odaküldött bennünket a Lélektan Tanszék, ahol tanították azt, amire nekünk éppen szükségünk volt, és amilyen szakértelem a tanszéken akkor még nem volt jelen. A TTK-n hallgattunk biológiát, az orvosi egyetemen anatómiát, oda jártunk később boncolni is. Megválaszthattuk, hova megyünk gyakorolni, s mi mindenhova mentünk, ahol csak fogadtak. Az 1. számú Gyermekklinikán Liebermann Lucy és Popper Péter, az MTA Pszichológia Intézetében Gádorné Donáth Blanka, a József utcai Gyermek Ideggondozóban Polcz Alaine vezetett nekünk gyakorlatot. Egyszerüen nem tudtunk betelni azzal, amit nyújtottak, számunkra minden újdonság volt. A gyerekklinikán hallottunk először érdemben a pszichoanalízisről, követhettünk analitikus irányultságú gyerekterápiás folyamatokat, hárman Popperhez jártunk külön Rorschach-szemináriumra. Az MTA Gyermeklélektani Intézetében 
pedig ott volt egy kiváló team, ennek esetmegbeszélésein vehettünk részt. Nekem az egyetemen nem a magyar szak volt fontos, ott félig-meddig a Baránszky által tanítottakból éltem meg. Bár Paizs Dezső előadásai felejthetetlenek, Király István is valódi odafordulással dolgozott velünk, de az élmény a pszichológia szak volt, és az is, hogy nem mi teremtettük ugyan, de mi kezdeményeztük! Később persze biztosan indult volna 1956 után nélkülünk is.

\section{Egyetemi csoporttársaidra emlékszel?}

Ladócsy Mari ma is jó barátom, ő az 1. számú Gyerekklinikán évtizedekig dolgozott gyerek-pszichoterapeutaként. Földes Éva igazságügyi szakértő lett, egyikük fiatalon meghalt. Nagyon jól együtt gondolkodó, vitatkozó, érvelő társaság volt. Ugye végül most a tanítóképzőbe akarunk eljutni?

\section{Igen-igen. Odáig vezet az út.}

Minél előbb el akartam otthonról költözni, így egyetem mellett már harmadévesen vállaltam nevelői állást a cinkotai 12 évfolyamos iskola kollégiumában. Ott külön szobám volt, és óraadóként időnként helyettesíteni kellett. Magától értetődő volt, hogy amikor végeztem, ide kerültem tanárnak. Magyart és logikát tanítottam, osztályfőnöke voltam az egyik elsős gimnáziumi osztálynak.

Ekkor, 1962-ben került újra terítékre a Barlay-per. Behívtak a kerület oktatási osztályára, az osztályvezető a számba adta, hogy engem megtévesztettek, ezért kerültem szinte gyerekként az illegális hittanhálózatba. Azt válaszoltam, hogy „ma már máshogy gondolkodom, mint annak idején, de a hálózatban töltött évek életem fontos korszakát jelentik". Erre kaptam egy olyan határozatot, amely szerint „világnézeténél fogva pedagógiai munkára alkalmatlan”. Sokáig őriztem, azután a költözések során nyoma veszett a papírnak.

A forradalom leverése után úgy látszott, hogy az országban a mi életünkben gyökeres társadalmi fordulat nem következhet be. Nem mártír akartam lenni, egyszerűen képtelen voltam erről a nekem olyan fontos időszakról másként beszélni, de a helyzetet nagyon nehezen éltem meg. Éppen akkor végeztem, imádtam tanítani, és akkor úgy tűnt, soha többé nem tehetem.

Gimnazistakori szerelmemnek az édesapja gyerekorvos volt, ő szerzett nekem képesítés nélküli segéd csecsemőgondozói állást a Rege úti csecsemőotthonban. Ott dolgoztam egy évig. Közben Az MTA Gyermeklélektani Intézetében félállásban terapeutának alkalmaztak. A terápiához egyáltalán nem értettem, a klinikai 
pszichológiából az egyetemen semmit nem tanultunk, de az intézetben, főleg analitikus irányultságú, igényes pszichológusok vettek körül, tőlük az esetmegbeszéléseken, konzultációkon nagyon sok segítséget kaptam. Donáth Blanka megkért, segítsek válaszolni a kamaszoknak írt Lányok könyvére hozzá tömegével érkező levelekre. Persze csak az egyszerűbb levelek megválaszolásával bízott meg, és minden válaszomat kontrollálta. Egyszerủen a szárnyai alá vett. Ezzel kezdődött Blani haláláig tartó több évtizedes, szakmai és baráti kapcsolatunk.

\section{A napközibe beleszerettem, nagyon fontos szerepet játszott a pályámon}

Ebben az időben kezdett el Lénárd Ferenc egy gondolkodáslélektani kutatást, kísérleti iskolának az Arany János Iskolát választotta, és szólt nekem, hogy üres napközis állás van az Aranyban. Ő úgy tesz, mint aki nem tud semmit úgynevezett „politikai” múltamról. Pályáztam és megnyertem az állást. Volt egy osztályom, egyúttal napközis csoportom. Boldogan napköziztem, két osztályban magyart is tanítottam: visszataláltam a pályára. Néhány év múlva a szakfelügyelő javaslatára kineveztek napközis szakfelügyelőnek. Szakfelügyelőként Csepelen, Kőbányán, Rákospalotán jártam, igen fontos, a társadalom különböző rétegeinek érzékeléséhez nélkülözhetetlen tapasztalat volt. Később a Fővárosi Pedagógiai Intézetben napközis vezetőfelügyelő lettem. A napközibe beleszerettem, nagyon fontos szerepet játszott a pályámon.

Egy nap felkeresett Tordáné Hajabács Ili, a Budai Képző Neveléstudományi Tanszékének munkatársa. Napközis pedagógiát kell tanítania, de sose dolgozott napköziben, kérte, segítsek, mit tegyen. Kedves és nyitott volt, majd elment. Engem pedig elöntött az indulat: a kollegáim között ekkor már hárman doktoráltak napköziből, mindhárman komoly korábbi napközis praxis birtokában. Engem a doktorálás akkor, napközis nevelő koromban még érdekelt, nem akartam a napközis nevelói szereppel beérni, bárhogy szerettem is. Elkezdtem a doktori képzést a Lélektan Tanszéken, de a témavezetőm, Radnai Béla meghalt, én akkor vettem át a szakfelügyeletet, a doktorátus már nem volt fontos számomra. De volt három napköziből doktorált kollegám. Akkoriban jelent meg az Élet és Irodalomban egy hosszú elemzés a napközik helyzetéről. Erre a visszhang rovatba írtam egy cikket arról, kik tanítják, jó szándékkal, ám minden praxisbeli tapasztalat nélkül, és kiknek kellene tanítaniuk - a három kollegára utaltam - a napközis pedagógiát a Tanítóképzőben. 
A cikk megjelent, majd csörgött a telefon, Ungárné Komoly fudit hívott fel, és megkérdezte, nem akarok-e napközis pedagógiát tanítani? Mondtam, hogy nem magamat ajánlottam; erre hármunkat hívott meg a következő félévre óraadóként. Így kezdődött.

\section{A napköziről még mit szeretnél mondani?}

Beleszerettem, mert senki nem törődött azzal, mit csinálunk a gyerekekkel! Szabadok voltunk. Beleszerettem ebbe a szabadságba. Ráadásul az Arany János Is-

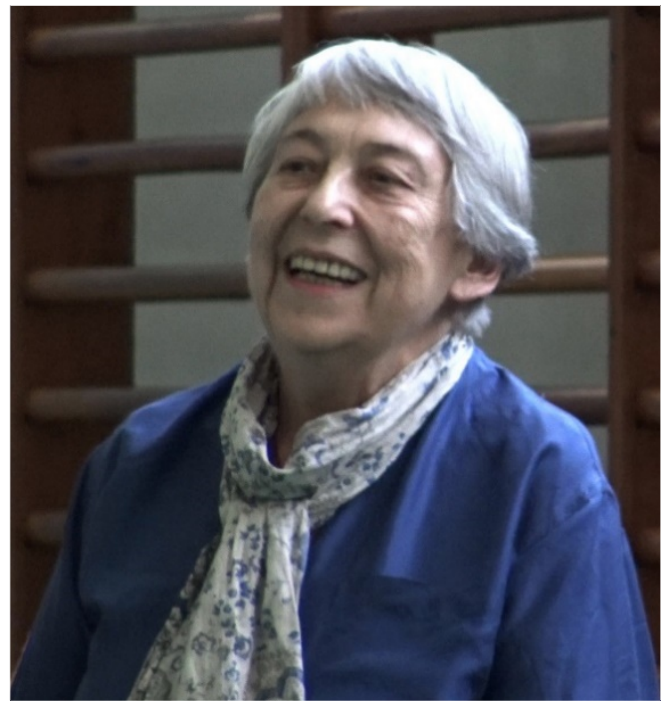
kola itt volt/van a Sas-hegyen, ennek a hegynek a túloldalán nőttem fel, minden követ ismertem. Angol tagozatos osztállyal dolgoztam, szinte naponta hat tanítási órájuk volt. Csak annyit kellett mondanom a gyerekeknek „Ennyi és ennyi időnk van délután. Ha nagyon figyeltek az órákon, és ha van rá időtök, valamennyit megcsináltok napközben a házi feladatból is, délután segítetek a házi feladat elkészítésében annak, aki kéri, akkor ennyi és ennyi szabadidőnk marad.” Erre egyszerűen megtáltosodtak. Megjöttek az iskolából, megebédeltünk, leültünk megbeszélni, mi történt velük, mióta nem találkoztunk, eldőlt, hogy aznap ki kinek segít, megcsinálták a leckét, és mentünk fel a Sas-hegyre játszani. Ha rossz idő volt, batikoltunk, szőttünk, máskor kirándultunk, jégpályát öntöttünk az udvaron. Úszni és futni jártunk. Éltünk.

Véletlenek összjátékából, abból ugyanis, hogy a Fővárosi Pedagógiai Intézetnek az a Kaján László volt az igazgatója, aki minden épkézláb innovációt támogatott, a Szegedi Tudományegyetemen volt egy iskolaotthonnal foglalkozó akciókutatás, Eperjessy Gézáné, aki előzőleg vezetőfelügyelő volt a Fővárosi Pedagógiai Intézetben, megalakította a Pedagógiai Társaság napközis szakosztályát, a szakosztály pedig országszerte megkereste a napköziben minőséget képviselő embereket. Remek csapat volt, szabadidő-pedagógiával kezdtünk foglalkozni, új szervezeti formák születtek. Az OPI az egész napos foglalkoztatás NDK-beli merev kereteit, az FPI, a Szegedi Tudományegyetem Pedagógia Tanszéke, valamint a 
Pedagógiai Társaság pedig a gyerekek iskolai szabadságának a lehetőségeit kereste, és találta meg a napközis szabadidő-pedagógiában, a klubnapköziben. (2011ben, amikor a Hoffmann-féle államtitkárság mintegy elrendelte az általános iskolai egésznapos foglalkoztatást minden tartalmi előkészítés, a minimális tárgyi feltételek biztosítása nélkül, írtam a Tanítóban annak a mintegy húsz évnek a történetéről, a napközi kegyelmi időszakáról, fénykoráról.) $)^{2}$

Ez egy országos, a jó értelemben vett világmegváltó csapat lett. Hány év volt?

1964-ben kerültem az Aranyba, négy évig voltam napközis csoportvezető, '68tól '72-ig voltam Csepelen, Kőbányán, Rákospalotán szakfelügyelő. Nagyon más világ volt, mint az Arany világa, vagy akár Cinkota. Felfedeztem, láttam, hogyan lehet iskolázatlan szülők gyerekeivel, akár negyven gyerekkel is egy napközis csoportban jól élni.

1972-ben kerültem az Fővárosi Pedagógiai Intézetbe, 1975-ben lettem vezető felügyelő, '84-ben vettem át az OPI alsó tagozatos osztályának a vezetését. Ungárné Komoly fudit meghívásával pedig egy huszonöt évig tartó képzőbeli munka kezdődött el. Először az esti tagozaton, képesítés nélkülieknek tanítottam napközis pedagógiát. A hallgatók semmilyen képzéssel nem fertőzött fiatalok, sokan közülük vidékiek voltak, akik a képzés és a vele járó munka kedvéért költöztek Pestre. Remek volt akkor ez a képesítés nélküli csoport, akiknek érdekük is volt, hogy jól teljesítsenek, a munkájuk függött ettől, és befogadták, amit az ember a pedagógiából táplálékul kínált nekik.

Annak idején, az egyetemen a pszichológiával érdemben először találkozva az izgatott, hogyan lehet a fejlődés-, személyiség-, csoportlélektan segítségével jobban megérteni önmagamat, az egyes emberek, csoportok, iskolai osztályok viselkedését. Mindig azzal „játszottam’, hogyan lehet a pedagógiát úgy tanítani, hogy abból élő, hús-vér gyerekkel valódi kapcsolat alakulhasson. A képesítés nélküliek még közel voltak a középiskolához, tele voltak saját friss iskolai élményeikkel, öröm volt velük együtt fedezni fel például volt tanáraik és a saját iskolai viselkedésük közötti összefüggéseket.

Amikor az Országos Pedagógiai Intézetbe kerültem, akkor készült az új Óvodai Nevelési Program, akkor folytak a '78-as tantervi átalakítás előkészületei. Alsó tagozatban sose tanítottam, ezzel az érvvel utasítottam vissza először az alsós osz-

\footnotetext{
${ }^{2}$ Kereszty Zsuzsa (2011): Volt egyszer egy napközi / Kezdetben szubjektíven, majd szigorú tárgyilagosságra törekedve az egésznapos nevelésről. Tanító Módszertani Folyóirat
} 
tályvezetői munkára való felkérést. Szabolcsi Miklós azzal érvelt, hogy a tantárgypedagógusok értenek a tantárgyaikhoz, osztályvezetőnek olyan emberre van szükség, aki a gyerekekhez ért. Ennek a mondatnak, nem tudtam ellenállni, úgy gondoltam, a napköziben szerzett tapasztalataimat a program- és tantervfejlesztésben kitűnően felhasználhatom.

A képzőben ${ }^{3}$ - Hunyady Zsuzsával együtt dolgozva -, nem külön napközis pedagógiát, hanem szabadidő-pedagógiát kellett tanítani. Tanulnak a hallgatók ének-zenét, sportot, művészeti tárgyakat, magyar irodalmat, pedagógiát, pszichológiát. Minden tárgyat úgy jó tanítani, hogy benne legyen az is, mit lehet a szakdidaktikai tudással kezdeni a tanórán kívüli (napközis) időben is. Ez persze vágy, amely csak az alternatív iskolák egy részében vált azóta praxissá. Külön napközis pedagógiát nem, de szabadidő-pedagógiát fontos tanítani, s ebben ötvözhető az a tudás, hogy a különböző tantárgyak tartalmából mit, hogyan jó használni a gyerekek szabadidejében.

A gyermekterápiákról azt mondtad, nem értettél hozzá, de csináltad. Hogyan befolyásolt, milyen hatással volt a gondolkodásodra, milyen élmény?

Nagyon jó kérdés! Kezdő voltam, könnyűnek ítélt eseteket kaptam, és hetente volt esetmegbeszélés. Beletemetkeztem a gyerekterápia szakirodalmába, újraolvastam a gyerekklinikai esetekről készült jegyzeteimet és kérdeztem. Ez mindöszsze másfél év volt. Volt egy enuretikus kislány, felvettem az anamnézist, a gyerekkel elkezdtem a szakirodalom, valamint az intuícióm szerint dolgozni, közben az enurezis váratlanul megszűnt; én pedig nem értettem, mitől. Megkérdeztem az édesanyját, hogy szerinte mitől gyógyult meg a gyerek, mert abban biztos vagyok, hogy nem én gyógyítottam meg. Azt válaszolta, hogy a napközitől. Elmentem megnézni, milyen az a napközi, amitől egy enuretikus gyerek meggyógyul és a Mártonhegyi úti iskolában ott találtam egy Palotás Márta nevű varázslónak a napközijét.

Ha az ember másfél éven keresztül, kvázi hetente részt vesz esetmegbeszéléseken, akkor jóval mélyebben kezdi látni egy gyerek müködésének okait. A legfőbb tapasztalat az volt, hogy ez nem nekem való munka, ahhoz túl direkt vagyok. Ugyanakkor mély kapcsolatot őriztem egész pályámon a pszichológiával mint szakmával. Ebben nagy segítségemre volt egyetemista korombeli gyakorlatvezetőm, Gádorné Donáth Blanka, aki meghívott társvezetőnek az általa pedagógusok-

${ }^{3}$ Budapesti Tanítóképző Főiskola 
nak vezetett encounter csoportokba. Az ülések után emlékezetből jegyzőkönyvet készítettünk a csoporttörténésekről, részletesen megbeszéltük a csoporttagok által hozott eseteket, a résztvevők csoportbeli viselkedését, a lezajlott csoportdinamikai folyamatokat, benne a kettőnk szerepét. Így mélyült el a pszichológiával mint szakmával a kapcsolatom. Később, a Tanítóképzőben is vezettem önismereti irányultságú esetmegbeszélő csoportokat, közben Gádor Pannit kértem szupervízióra.

Köszönöm szépen! Részleteznéd a tanitóképzéssel, a felsőoktatással való kapcsolódásait az életednek?

Az OPI-ban munkakörömhöz tartozott, hogy elmélyedjek az olvasás-írás tanulás és -tanítás rejtelmeiben. Akkoriban új és új programok születtek. Mivel sose tanítottam írni-olvasni, így többeket - akik a folyamatot a praxisból vagy kutatóként mélyen értették ${ }^{4}$ - felkértem, elemezzük együtt valamennyi módszert, olvasókönyvet, hasonlítsuk össze őket egymással, és vessük össze fejlődéslélektani tudásunkkal a módszerek révén közvetített, a gyerekben az írás-olvasás tanulása közben lezajló, átélt folyamatot. Eközben találtam rá a Waldorf írás-olvasás tanítási módszerére. Az összehasonlító elemzés befejeztével a szakértőcsoport számára nyilvánvalóvá vált, hogy ez a módszer hat a mozgáson, látáson, halláson, képzeleten keresztül a legmélyebben. Így kezdődött a kapcsolatom a Waldorf-pedagógiával.

A tanítóképzőben tovább vezettem esetmegbeszélő csoportokat, közben a Waldorf-pedagógia és a Szabad Iskolákért Alapítvány révén egyre szorosabb kapcsolatba kerültem az alternatív mozgalommal. Ott voltak a gyerekkori Új Iskolás élmények, az új Waldorf-pedagógiai tapasztalat, így természetes volt, hogy bekapcsolódtam - a Czike Detti és Békési Ágnes által szervezett - alternatív pedagógusképző műhely munkájába. ${ }^{5}$ A Műhely tagjai iskolaalapítók, alternatív iskolák vezetői, tanítói, tanárai, szervezői voltak. Az ő szemükkel is nézve, egyre több szempontból, egyre tágabban láttam azt a praxist, amely az iskolát kezdő gyerek számára kívánatos lenne.

Közben a Gyógypedagógiai Főiskoláról megkeresett Csányi Yvonne, aki szeretett volna egy inklúzióval kapcsolatos könyvet kiadni az OPI közreműködésével. Megismerve a kéziratot, megragadott az integráció mint gondolat, szándék. A OPI

${ }^{4}$ Kádárné Fülőp Judit, Szilágyi Imréné, a Szegedi Tudományegyetemről Nagy fózsef.

${ }^{5}$ Mai nevén a Szabad Iskolákért Alapítvány Pedagógiai Mủhelyéről van szó. 
Mihály Ottó vezette Iskolafejlesztési Központja kiadta a könyvet. Közben a Csányi Yvonne tanszéke az integráció tanulmányozását szolgáló nemzetközi pályázatot nyert, Yvonne pedig felajánlotta a Budapesti Tanítóképző Főiskola Neveléstudományi Tanszékének a programban való részvételt. A lehetőséget tanszékvezetőként Hunyady Zsuzsa szívesen fogadta.

A program lényege: keressük meg minden tanszéken azt a kollegát, aki nyitott az integrációra, és vonjuk be a programba. Hallgatók jöhettek velünk Cambridgebe, Manchesterbe integrációt tanulni, gyakorolhattak egy hónapig angliai iskolában. Minden tanszéken találtunk a programba szívesen kapcsolódó, az integrált tanításra nyitott kollegát. Képzőbeli életem fantasztikus időszaka volt, szoros munkakapcsolatba kerültem Szendrei fulival, Demeter Katival, Bálványos Hubával és másokkal. Tudtunk együtt gondolkodni.

Kevés ennél izgalmasabb programot éltem át. A Neveléstudományi Tanszék hallgatói pályázatot hirdetett, az elbírálás kritériuma a nyelvtudás színvonala, valamint a hallgató integrációhoz való viszonya volt. A nyertesekkel, tizenöt hallgatóval együtt mentünk képzésre Heidelbergbe, Londonba. Esténként hosszan elemeztük a napi tapasztalatokat. Akkor ismertem meg az angol nemzeti alaptantervet, tapasztaltam meg azt a képzési módot, amellyel bennünket, oktatókat képeztek a cambridge-i intézetben ${ }^{6}$ és a manchesteri egyetemen. Ennek a programnak az összegzése, végterméke a Budai Képző tantervének az integráció szempontjából való bővítése, átdolgozása lett, ennek létrejöttében Hunyady Zsuzsának meghatározó szerepe volt. Minden tanszék kidolgozta, hogy a meglévő tantárgyak hogyan ölelhetik magukba a sajátos nevelésre való felkészülést. A pedagógiai, pszichológiai tantárgyakat Kolozsváry fudittal dolgoztuk át.

\section{Havonta lejártam Csenyétére egy csereháti magyar cigányok lakta faluba}

Ebben az időben állított be hozzám egy hátizsákos fiatalember Pólya Zoltán, és arra kért, mondjam meg, mit tanítson a menyasszonya egy csereháti magyar cigányok lakta faluban, Csenyétén, mert a központi tanterv az ő tanítványai számára biztosan nem releváns. Mivel erre a kérdésre lehetetlen volt a képző egyik szobájából válaszolni, új szakasz kezdődött az életemben. Havonta lejártam Csenyétére, együtt alakítottuk ki először két, majd több tanítóval a gyerekeknek jó, pillanatnyi

\footnotetext{
${ }^{6}$ Cambridge Institute of Education
} 
állapotukból induló, az országos tanterv követelményei felé futó tantervet. A faluban szerzett tapasztalatok az életfelfogásomat is megváltoztatták.

\section{Mondanál egy konkrétumot: miért, hogyan módosult az életszemléleted?}

Megtanultam becsülni a falu embereit, egyesek morális tartását. Az egyik csenyétei asszonynak, Mónikának a kisfia nyaki gerincvelő-sérüléssel, aszfixiásan, négy béna végtaggal született. Erős élmény volt, ahogy Móni a sérült kisfiához viszonyult. Reggelenként hozta a másik két gyerekét iskolába, karikás szemekkel, érzékelhetően fizikai erőinek a határán járva. Láttam, milyen állapotban van, próbáltam rábeszélni, hogy legalább egy hétre vigye kórházba a kicsit, addig kipihenné magát, hiszen hetek óta alig aludt éjjelente, a béna kisfiú életjeleit figyelte. Mónika válasza ennyi volt: „Nem viszem sehova, ez is egy élet, fel kell nevelni”. Azokban a napokban tudtam meg, hogy egyik legjobb barátom, aki orvos és hitelesen vallásos ember volt, értelmi sérült kisfiát intézetbe adta. Hetente látogatták, időnként hazavitték, de a kudarccal, amely a fogyatékos gyerekben testesült meg, nem tudtak naponta szembesülni. A kontraszt a két eset között nagyon erős volt. Persze ez csak két ember, két szülő különböző szemlélete, mégis egy keresztény értelmiségi és egy iskolázatlan cigányasszony gyökeresen másképp reagált a nagyon hasonló helyzetre. Ettől kezdve eszembe se jutott általánosítani, végképp nem létezett számomra olyan kategória, mint például „vallásos értelmiségi” vagy „iskolázatlan cigány”.

\section{Értem.}

A másik döntő élményem a saját helyem a faluban. Egy nagyon tehetséges fiú továbbtanulásához szerettük volna kérni a szülők támogatását, tanítójával, a remek Komaság Margóval. A nagycsalád számos tagjával ültünk egy este Horváthéknál. Beszélgetés közben belépett a házba egy idős férfi, és leült mellém. Be akartam neki mutatkozni, mire megszólalt: „Tudom én, ki maga! Maga a mienk!”. Később kiderült, az egyik gyerek nagyapja azok közül a kicsik közül, akikkel többször tanultunk együtt.

Ez a mondat számomra azt jelentette, hogy befogadott egy cigány falu. Nagy élmény volt! A tanítókkal való együttműködés közös problémamegoldást jelentett. Ennek eredményeként a tanítók - elsősorban Komaság Margó és Pólya Zoltán jóvoltából -, összevont osztályok számára érvényes, alternatív praxis született Csenyétén. 
A központi, minisztériumi előírás pontosan megszabta, melyik évfolyam tanulói melyik tantárggyal naponta, illetve hetente hány percet foglalkozzanak. A tanítók számára ez abszurd helyzetet teremtett, hiszen éppen akkor kellett (volna) új tantárgyra váltani, amikor a gyerekek már belemelegedtek a tanulásba, képesek voltak az éppen aktuális témára és feladatra koncentrálni.

Kiszámítottuk, hogy a négy évfolyam számára egy tanévben melyik tantárgyra mennyi idő jut, az összes időt elosztottuk úgy, hogy a gyerekek mind a négy évfolyamon ugyanazon a napon ugyanazzal a tantárggyal foglalkozzanak. Így lehetett például az egyik napon írni, olvasni, mesét hallgatni, dramatizálni, másnap tárgyak, személyek sokaságának a hosszát, szélességét, magasságát alkalmi és szabályos mérőeszközökkel megállapítani, majd együtt gondolkodni azon, miért is van szükség közös mértékegységekre és így tovább.

Felejtsük el, melyik gyerek hányadik osztályos, s aszerint adjunk kinek-kinek olyan feladatot, amelyet optimális megterheléssel meg tud oldani. A Waldorfpedagógia epocha rendszere volt az ihlető, a feladatokat pedig differenciáltuk.

\section{A differenciálás értelmezési tartományai}

Hogyan tudtad ezt a tudásodat, tapasztalatodat a tanitóképzésbe visszaforgatni?

Göncz Árpád köztársasági elnök felhívta a főigazgatót, és megkérdezte, indítana-e a képző cigány szakkollégiumot. A fóigazgató magáénak érezte Göncz Árpád szándékát. Mivel az oktatók között nem volt más, aki cigány gyereket közelről látott volna, a kurzus megszervezését rám bízták. Tudtam, hogy nem értek hozzá, és azt is, hogy ki az, aki ért. Így felkértük Kovalcsik Katalint, az MTA kutatóját, Csongor Anna szociológust, állítsák össze a szakkollégium programját. Két féléven keresztül tanítottak, rendre meghívva egy-egy részterület legjobb szakembereit, Réger Zitát, Szuhay Pétert, Havas Gábort és másokat. A kurzus érdekes, vonzó volt, többen végezték el, mint ahányan kezdetben felvették. Szívesen, jó színvonalon kollokváltak, majd azt kérték, a kollokviumi jegyet ne írjuk be az indexükbe: ha ugyanis kiderül, hogy szakkollégiumot végeztek, nagyobb az esélyük arra, hogy cigány osztályban kell majd tanítaniuk.

Ekkor döbbentünk rá, hogy bármilyen jó is a szakkollégium, sose lehet valódi megoldás. Valamennyi tanszéken, valamennyi tantárgy oktatásában dolgoznunk kell a hallgatók szemléletének alakításán. A Neveléstudományi Tanszék pályázott és nyert egy, a „Kísérlet a roma gyerekek nevelésében (is) kompetens tanítókat ki- 
bocsájtó tanítóképzés létrehozására" című Phare-pályázaton. A program keretében, valamennyi tanszék egy-egy munkatársát bevonva, négy évig dolgoztunk együtt egy hallgatói csoporttal.

A tiszabői és a londoni Hackney-negyed iskolája volt a partneriskolánk, a hallgatókkal ezekben hospitáltunk, Tiszabőn a hallgatók gyakoroltak is. A hajdani szakkollégium tanárai pedig megírták a képzés számára a Tanítók Kiskönyvtára sorozat Tanulmányok a cigányság társadalma és kultúrája köréből című kötetet. ${ }^{7}$

Munkám a képzőben a napközis, majd a szabadidő-pedagógia oktatásával kezdődött, önismereti irányultságú, esetmegbeszélő csoportvezetéssel folytatódott, ezt követte a sajátos nevelési igényü, majd a cigány gyerekek nevelésére érzékenyítő képzés.

Mindebből következett az a felismerés, hogy ha a roma integráció, az SNI-inklúzió gyakorlatát terjeszteni szeretnénk, akkor ezt a már végzett tanítók számára célszerüen a személyre szabott tanítás, a differenciálás gondolatkörében, gyakorlatában tehetjük meg. Mindehhez a gyakorlóiskolával való együttműködésre lett volna szükség. Az SNI-integrációt célzó projektet előkészítő megbeszélésen az igényes, szakmailag képzett gyakorlóiskolai igazgató azt találta mondani, hogy a gyakorlóiskolának a képzés a feladata, így a tanítók, tanárok nem érnek rá speciális szükségletű gyerekek integrációjával foglalkozni. Hunyady Zsuzsával, Kálmánné Bors Irénnel közös döntésünk volt, hogy ezek után gyakorlóhelyül ne a gyakorlóiskolát, hanem az alternatív iskolák egyikét válasszuk. Így kezdődött a képző együttműködése a Gyermekek Házával, ahol akkor már szellemében és gyakorlatában jól kimunkált inkluzív nevelés folyt. A Gyermekek Háza tanáraival, a tanszék és a Bárczi Gusztáv Gyógypedagógiai Kar néhány oktatójával vetünk részt cambridge-i, manchesteri képzésen, hallgatóink a Gyermekek Házába jártak hospitálni. A program a képzés egészét sajnos nem érintette, a programban egyetlen hallgatói csoport vett részt négy éven keresztül.

Az Országos Pedagógiai Intézetet közben átszervezték, az alsó tagozatos osztály megszűnt, Mihály Ottó kitűnő Iskolafejlesztési Osztályára kerültem, majd a képzőbe adjunktusként, később docensként. A differenciáló szakirányú képzést akkreditálták, évekig nyugdíjasként is ebben a programban dolgoztam. Ez a képzés megkísérelte egyesíteni azt, amit a napközis pedagógiában, a cigánygyerekek integrációjában, a speciális szükségletűek inklúziójában megtapasztaltunk.

${ }^{7}$ A Kovalcsik Katalin által szerkesztett kötet, az ELTE, az Oktatási Minisztérium és az Iskolafejlesztési Alapítvány közös kiadásában jelent meg 2000-ben. 
Többször említetted a hallgatókkal való kapcsolatodat, kérlek, beszélj erröl, illetve ennek a változásáról!

A napközis pedagógia tanításának idején egyszerűen lelkesen előadtam, ügyelve arra, hogy kérdezzenek, és próbáltam a csoport közös gondolkodását a lényeges problémák felé terelni. Az alternatív iskolák praxisát látva, a Kagan-monográfiát $t^{8}$ megismerve elkezdtem alkalmazni a kooperatív módszereket. Van is a tanszéknek videófelvétele az egyik ilyen órámról. Majd Hunyady Zsuzsa megszervezte, hogy a Szabad Iskolákért Alapítvány munkatársaiként tartsunk Czike Dettivel kooperatív tréninget a képző oktatóinak és a gyakorlóiskola tanárainak. Érdekes helyzet volt. Kooperatív foglalkozásokat vezetve sokféle információt kaptunk arról, mit is gondolnak a résztvevők magáról a tanulási- és tanítási folyamatról. Differenciálást pedig abszurd anélkül tanítani, hogy ne kísérelnénk meg a résztvevők egyéni szükségleteit figyelembe venni. Az esetmegbeszélő csoportokban a csoportvezető valamennyi résztvevővel óhatatlanul személyes kapcsolatba kerül. Nem véletlen például, hogy három volt csoporttaggal több mint húsz éve vagyunk szakmai- és baráti kapcsolatban. Hogyan érted a változást?

Úgy, hogy Benned volt-e változás az idók folyamán, a módszereidben, a hallgatók felé fordulásban? Azonnal megtaláltad azt az utat, amelyen hallgatókkal tudsz menni, haladni?

Megrázó élményem, amely nyilvánvalóvá tette, hogy a legfőbb cél nem lehet más, minthogy a tanítók ne padban ülő, tanítást befogadó tanulónak, hanem teljes lényükre figyelve, önálló személyiségnek lássák a gyerekeket. Egyszer azt a feladatot adtam, rajzolják le azt a gyereket, akivel most a legtöbb problémájuk van. A huszonvalahány tanítóból tizenöt deréktól felfelé rajzolta le a számára „nehéz” gyereket, úgy, ahogy kilátszik a padból; olyan is volt, aki csak a gyerek fejét vázolta.

Ekkor tettem félre az akkreditált program tematikáját. Sorra vettük a résztvevők tanítással, gyerekekkel való kapcsolatával összefüggő problémáit. Ha a számfogalom alakításában akadtak el, akkor jött 10-15 tanítványával Kocziha Miklós Waldorf-tanár, és szám- és műveletfogalom alakítását segítő mozgásokat tanított9. Ezt kiválóan lehetett értelmezni a gondolkodásfejlődés áttekintésével, azaz a kur-

${ }^{8}$ Kagan, S. (2012): Cooperative Learning Structures. magyarul: Kagan, S. (2004): Kooperatív tanulás. Ökonert, Budapest.

${ }^{9}$ Lásd: Kocziha Miklós: Számolás, mozgás, ritmus https://www.youtube.com/watch?v=4bgGsfgQ_9c 
zus egyik „hivatalos” témájával. Sorra vettük a résztvevők nehéz gyerekeit, mintegy esetmegbeszélő csoportként müködtünk. Persze a résztvevők problémái köré koncentrálva a kurzus eredeti tananyagát, végül minden tantervi témára sor került.

\section{Hogyan kerültél a Waldorf-pedagógia közelébe?}

Ahogy már említettem, az írás-olvasás tanításon keresztül. Az Országos Pedagógiai Intézet úgynevezett alsófokú osztályának vezetőjeként szakértők csoportjával vizsgáltuk, melyik írás-olvasás tanítási módszer a legeredményesebb, és nyilvánvalóvá vált, hogy az írással kezdő, mozgásos emlékezetre is építő, a gyerekek aktuális fejlettségéhez simuló Waldorf-módszer felel meg legjobban. Ekkor kezdett el mélyen érdekelni a Waldorf-tanítás egésze. Hallgatókkal Bécsbe kirándultunk, láttuk a Waldorf Iskola előtt a reggeli kézfogáshoz érkezni az első, a tizedik, a negyvenedik gyereket. A tanár és a gyerekek közt a kézfogás alatt egy-két pillanatra megszülető kapcsolatot személyesnek, frissnek tapasztaltuk. A nagyszünetben az ötödikesek nyitva hagyták számunkra görög epocha füzeteiket. Így negyven szépséges füzetbe pillanthattunk bele. Ezidőtájt született meg az első magyar Waldorf-tanterv, ezt kellett a döntéshozókkal elfogadtatnia az első Waldorf-iskolának, a pesthidegkútinak, pontosabban a Magyar Waldorf Egyesületnek.

Nagy élmény volt számomra, hogy az OPI osztályvezetőjeként ebben közremüködhettem. Kovács Gáborral, aki akkor iskolaképviselő volt Hidegkúton, s még néhány tanárral dolgoztunk együtt, és élveztük azt a folyamatot, amelyben bemutattuk, minként nyújt nem csupán annyit, hanem jóval többet a Waldorf-tanterv, mint amennyit az országos központi tanterv elvár.

Megtaláltam a gyerek fejlődésének megfelelő pedagógiát, ők bennem azt a „hivatalban” lévő személyt, aki segíteni tud nekik abban, hogy a döntéshozók ezt a pedagógiát befogadják.

Beöthy Hanna, az első hidegkúti osztály kísérője kért, legyek az első végzős osztály érettségi elnöke. Korábban ezt a szerepet sose töltöttem be, az iskola kedvéért közoktatási szakértőként megpályáztam az értékelés-szakértői szerepet, és kértem, hogy arra való tekintettel, hogy az alternatív pedagógiák a kutatási területemhez tartoznak, lehessek az első érettségiző Waldorf-osztály érettségi elnöke. Később másutt is voltam elnök, és a különbség a waldorfos és a többi érettségiző diák között számomra elképesztő volt. 
Volt egy lány a hidegkúti osztályban, aki diszfáziával, diszlexiával összefüggő fejlődési zavar tüneteit mutatta. Biztos vagyok benne, hogy hagyományos tantervü gimnáziumban nem jutott volna el az érettségiig. Közben zseniálisan rajzolt, festett. Angol helyett földrajzból érettségizett. Így beszélt: „... termesztenek, nem termelnek; szént, nem szenet”, de minden fontosat kitűnően tudott Franciaország iparáról; felelés közben nyugodtan kereste a szavakat, tudta, hogy türelemmel várják, amíg megfogalmazza mindazt, amit tud. A rajzai fantasztikusak voltak. A diákok történelem feleletei az adott kor képzőművészetéről, zenéjéről, irodalmáról és történelméről egyaránt szóltak. Nem azért, mintha a waldorfos gyerekek müveltebbek lettek volna, mint mások, hanem mert epochákban tanultak, s az epochákban mindez együtt, egymásra vonatkoztatva jelent meg. Ettől kezdve számomra magától értetődő volt, mindent meg kell tenni, hogy az érettségi után Waldorf-diplomát szerző pedagógusok minél előbb állami diplomához juthassanak. Ekkor indult el az a kétféle tantervet összehangoló munka, amely Mikonya György dékán támogatásával, nagyrészt Rádi Orsolya és Kulcsár Gábor munkájával, a solymári Waldorf Pedagógiai Intézet vezetőjével együttműködve született, s aminek eredményeként már végzett, és állami tanítói diplomát szerzett az első csoport a budai képzőben. (Most a Waldorf-pedagógiáról beszélünk, de hangsúlyozni szeretném, hogy a Carl Rogers Személyközpontú Iskolában egyéni tanterv szerint is tanulnak azok a gyerekek, akiknek erre szükségük van.)

Saját személyes életed hogyan kapcsolódott össze a Waldorf-pedagógiával?

Van egy kolozsvári keresztfiunk, akinek az apja a Babeş-Bolyai Egyetem tanára, anyja néprajzos. Az anya, talán rajtam keresztül is, rájött a Waldorf-pedagógia ízére, Budapesten szerzett Waldorf-tanári képesítést. Amikor a gyerekei óvodáskorúak lettek, többekkel együtt Kolozsváron Waldorf-óvodát, később iskolát alapítottak. Természetesen magyar és román osztállyal. A két gyerek, Salat-Zakariás Csaga és Soma Waldorf-óvodások és Waldorf-iskolások lettek. Láttam, ahogy énekelnek, táncolnak, láttam a számtanfüzeteiket, tudtam, hogy ritmikus rész, meseés történetmondás szövi át a napjaikat. Apjuk mindezt jó szemmel nézte, de mikor nyolcadikosok lettek, úgy érezte, szép, szép, eddig eljátszadoztak, de legalább középiskolában „tanulják meg, hogy kell komolyan tanulni”. A kitűnő apa, első generációs értelmiségiként, kisebbségiként, a Ceaușescu-rendszerben illegálisan működő Ellenpont csoport tagjaként, a Securitatae által megfigyeltként, keményebb élethez szokott, mint amelyben gyerekeit kamasszá nőni látta. Zakariás Er- 
$z$ sébet, az anya és iskolaalapító persze azt szerette volna, ha a gyerekek középiskolás éveiket is Waldorf-iskolában töltik. A döntés előtt eljöttek hozzánk mint keresztszülőkhöz, mondjuk el a gyerekek továbbtanulásáról a véleményünket. Zakariás Pendzsi persze azt remélte, hogy az ő véleményét erősítem meg. Tudtam, hogy a Waldorf-középiskola lenne jobb a gyerekeknek, de nem mondhattam mást, minthogy az apa akaratával szemben nem jó dönteni.

Az állami gimnáziumban Somát az első hetekben kinevette az osztálya, mert tizennégy évesen egy nagy, széles karimájú fekete kalapban járt iskolába, „egyénieskedni” pedig a diktatúra utáni Romániában nem volt szokás. Aztán mindig megcsinálta, amit tanárok mondtak: megírta a leckét például, a Waldorf-iskolában alig

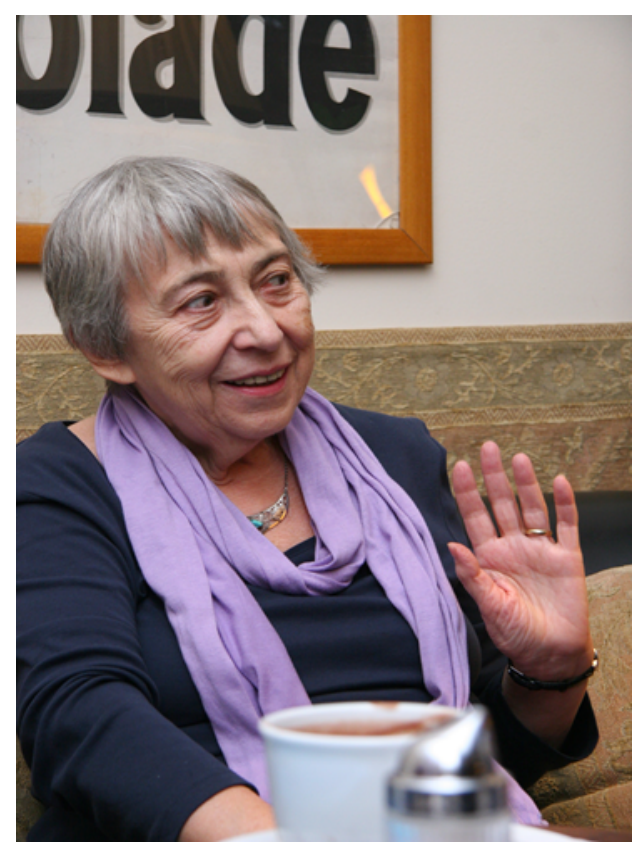
volt lecke, ez számára újdonság volt. Soma, a kalapos, leckét megíró új fiú addig volt nevetség tárgya az osztályban, amíg el nem érkezett az a pillanat, amikor matematika dolgozatot akart íratni velük a tanáruk, s az osztály többsége nem érezte úgy, hogy tudják, ami a dolgozathoz valószínűleg kell. Soma felvetette, beszéljék meg ezt a tanárral, hiszen megszokta, hogy a tanárokkal lehet beszélni. „Megbeszélni a tanárral? Hülye vagy te Soma, a kalapoddal együtt." - mondta az egyik fiú. „Fogadjunk, hogy elintézem!”mondta Soma, és megbeszélte a tanárral, hogy még gyakoroljanak, és egy héttel később írják meg a dolgozatot. Ettől kezdve fogadta be Somát az osztály. Soma most nemrég Baselban régizene szakon szerzett művésztanári diplomát. A nővére, Csaga Sepsiszentgyörgyön formatervező. Az iskolai pályafutásuk volt az első erős személyes élményem a Waldorf-pedagógia gyakorlatáról. Sajnos Nagyváradon - ahol az unokáim élnek - még csak Waldorf-óvoda működik.

\section{Most könyvet írsz.}

Lányi Mariettával írtunk könyvet a differenciálásról, a SuliNova-Educatio megrendelésére. 2008-ban megjelent, és azután megváltozott az oktatáspolitika, és a 
kötet raktárban maradt. ${ }^{10}$ Hoffmann Rózsa lett az államtitkár, aki a tanévnyitó konferencián bejelentette: „A Waldorf-iskoláknak nem kell félniük.” Ebből arra lehetett következtetni, hogy a többi alternatív iskolának viszont van mitől félnie. A Waldorf-iskolákat feltehetően nemzetközi hálózatuk, erejük, egyesületük védi. A kármentés szándékával kezdtem el a Gyermekek Háza tanáraival, szüleivel egy interjúkötetet létrehozni. Szerencsére a Műszaki Kiadó nem csak ezt az interjúkötetet adta ki, ${ }^{11}$ hanem a differenciálás kötet bővített változatát is.

Mindannak fényében, amit itt most átgondoltál a Tanitóképzőről is meg az életedről is, mit jelent számodra az, hogy itt dolgoztál az ELTE Tanitó- és Óvóképző Kar Neveléstudományi Tanszékén?

Nehéz pontosan fogalmazni, mert egyrészt számomra fantasztikus lehetőség volt, hogy amit a különböző terepeken: Csenyétén és az alternatív iskolákban megtapasztaltam, amilyen tudást próbáltam folyamatosan megszerezni, azt kíséreljem meg átszármaztatni. Ez fantasztikus élmény, és úgy éreztem, hogy a leendő tanítóknál jobb helyre mindez nem is kerülhetne.

Ugyanakkor azt is gondolom, hogy nem ez a valódi tanítóképzés. Nem válik tanárrá valaki attól, hogy különböző tantárgyakat tanul, majd ebből gyakorol. A valódi tanítóképzés az önnevelésre rásegítő munka lenne, amit nagyon is személyre szabottan kellene művelni.

Ez persze felemás válasz. Mondhatnám azt is, hogy nekem csodálatos kibontakozás volt a tanítóképzős lét, és ez igaz. És mondhatnám azt is, hogy szinte teljesen értelmetlen volt, és ebben is van igazság. Pusztán attól, hogy jó tanárai voltak, még nem lesz jó tanító vagy jó tanár valaki. (Most megengedtem magamnak, hogy a jobbak közé soroljam magam, persze a képzőbeli időszakban egyáltalán nem egyenletesen.)

Egyes embereknek - igen ezt lehet tudni - egy-egy kritikus periódusban lehet segíteni. Angéla egy észak-magyarországi szegény falu iskolázatlan cigány párjának a gyereke, aki a képző hallgatója volt, és szerinte közremüködtem abban, hogy egy nehéz élethelyzetben ne hagyja ott a Budapesti Tanítóképző Főiskolát. Angéla maradt a képzőben, közben elvégezte a szociológia szakot is, a Középeurópai Egyetemen angolul doktorált, most éppen vendégtanár Amerikában.

\footnotetext{
${ }^{10} \mathrm{Az}$ interjú után egy évvel a Műszaki Könyvkiadó megjelentette ennek átdolgozott, bővített kiadását: Kereszty Zsuzsa - Lányi Marietta (2017): Könyv a differenciálásról. Műszaki Kiadó, Budapest.

${ }^{11}$ Lányi Marietta - Kereszty Zsuzsa (2016): Történetek a Gyermekek Házából. Műszaki Kiadó, Budapest.
} 
Amennyiben a CEU életben marad, akkor szeptembertől ő lesz a Roma Studies tanszékvezetője. ${ }^{12}$ Angélának véletlenek folytán tudtam segíteni, hiszen akkor például már átéltem azt, amit átélni Csenyétén képes voltam. Sajnos azt a fajta képzést, amit művelünk, ma sok tekintetben értelmetlennek látom. Nemcsak önnevelésre, a szakmai fejlődés saját útjának a megkeresésére való késztetés hiányzik majdnem teljesen, hanem a hallgatók egyes osztályokkal, gyerekekkel való intenzív, tartós kapcsolata sincs jelen a tanítóképzésben.

Hunyady Zsuzsának és Gyóni Lajosné Zoskának volt egy képzést megújító kísérlete, amely sokkal hosszabb gyakorló időszakkal járt együtt. Ez a program abba az irányba indult el, amerre el kellene indulni. Nem véletlen, hogy a Waldorftanárképzés gyakorló évvel, iskolai jelenléttel kezdődik. Az sem véletlen, hogy a Waldorf-képzésben például egy hónapig kell egy fej agyagból való megformálásával törődni. Attól kezdve, hogy egy hónapon keresztül újra és újra megfigyelek egy fejet, és megpróbálom minél élethübben megalkotni, ettől kezdve másképp nézek rá egy gyerekre.

Nagyon szépen köszönöm a beszélgetést!

${ }^{12}$ Jelenleg, 2019 októberében, már be is tölti ezt a szerepet. 